\title{
The Impact of Overhead Cost Budgeting on the Annual Imprest Expenditures of State Ministries, Departments and Agencies (MDAs): A Study from Cross River State, Nigeria
}

\author{
William Smart Inyang ${ }^{1}$ \\ ${ }^{1}$ Department of Accounting, University of Calabar, Calabar, Nigeria \\ Correspondence: William Smart Inyang, Department of Accounting, University of Calabar, Calabar, Nigeria. \\ Tel: 234-703-630-6918. E-mail: obybam@yahoo.com
}

Received: April 7, 2013

Accepted: May 8, 2013

Online Published: May 17, 2013

doi:10.5539/ibr.v6n6p129

URL: http://dx.doi.org/10.5539/ibr.v6n6p129

\begin{abstract}
The excess of actual imprest expenditures over the overhead cost budgets of Cross River State Government Ministries, Departments and Agencies has not been given the attention it deserves despite the high frequency of its occurrence. More emphasis seems to be placed on the effects of the overall government budget on the actual general expenditure at the neglect of the effects which overhead cost budgets of MDAs have on imprest expenditures in the State. This study was therefore, carried out to fill this gap. Primary and secondary data were collected using questionnaires and office records respectively. Five hypotheses were formulated and tested by specifically applying inferential and parametric statistics to the primary data. The secondary data were specifically used to provide evidence for the identified research problem. The study revealed that overhead cost budgets, special imprests and additional imprests were ineffectively used. Secondly, even though previous studies showed that financial malpractices and poor budget monitoring were strongly associated with extra-budgetary expenditures in the 3 tiers of governments in Nigeria, the current study indicated that these two variables have little or no association and weak association respectively with extra-budgetary imprest expenditures in Cross River State MDAs. Inaccuracies in the overhead cost budgeting system were strongly associated with the extra-budgetary imprest expenditures. The study therefore, recommended that efficient and effective overhead cost budgeting system and regular budget review be put in place.
\end{abstract}

Keywords: extra-budgetary expenditure, MDAs, overhead cost budget, annual imprest expenditure, extra-budgetary imprest expenditure

\section{Introduction}

Cross River State like other States in Nigeria, exists to acquire and apply resources economically, efficiently and effectively for the benefit of its citizens. One of the instruments the State uses to achieve this laudable objective is the budget. Between 2007 and 2011, for no apparent reasons, three major Ministries, namely Ministry of Health, Ministry of Education and Ministry of Works exceeded their overhead cost budget limits by very wide margins of $\mathrm{N} 748 \mathrm{~m}, \mathrm{~N} 33.4 \mathrm{~m}$ and $\mathrm{N} 17 \mathrm{~m}$ respectively. (see table 1). These ugly trends therefore, suggest that the aforementioned overhead cost budgets were poorly implemented.

Nearly all organizations see budgeting as the cornerstone of the management control process and it is far from being perfect despite its widespread use. (Hansen, Otley \& Van der Stede, 2003). Norton and Elson (2002) said that Governments, civil society advocacy groups, research institutions and multilateral institutions have reached a consensus over a constructive general climate for debate on budget issues and there is a good level of communication and cross-referencing between the various groups and that there are still however, some areas of the budget process which are heavily contested. The areas of consensus that have been globally acknowledged according to Norton and Elson, are policy and planning, allocation of resources, budget allocation problem and budget execution. Budgets have also been acknowledged all over the world as useful tools for controlling public expenditure. Legislatures of various countries of the world have and are still using budgets to control the expenditures of their countries. Wehner (2006) used data for 36 countries from a 2003 survey of budgetary procedures to capture six institutional prerequisites for legislative control namely, amendment powers, revisionary budgets, executive flexibility during implementation, the timing of the budget, legislative committees 
and budgetary information. Wehner reviewed other institutional prerequisites and discovered huge differences in the level of control by the legislatures of present day democracies. The findings of Wehner suggest that budget is a key safeguard against the excesses of the executive.

Studies and reports on the causes of extra-budgetary spending in the annual budgets of Federal, State and Local Governments, have dominated public expenditure finance literature in recent times especially in Nigeria and some countries in Africa. Government Ministries, Departments and Agencies have continuously and unrepentantly exceeded their annual budgets (Olatunji \& Daniel, 2012; Omitoogun \& Oduntan, 2006; Umoru \& Shaibu, 2012). Rampant abuses of Government imprests have also been reported recently in Nigeria, Zambia and Tanzania respectively (AllAfrica.com, 2012; Ameh, 2012; "Government to recover unretired imprest", 2012; Tanzania Corruption Tracker system, 2012; Yovbi, 2007).

The poor implementation of the overhead cost budget has adversely affected most of the 63 MDAs in Cross River State and this problem still persists. The MDAs mostly affected have already been mentioned. Recurrent services that have also been adversely affected are: travel and transport, utility services, telephone services, stationery procurement, maintenance of office furniture and equipment, maintenance of motor vehicles and other capital assets, consultancy services, contribution and subvention, training and staff matters, establishment and hospitality and miscellaneous services. Government imprest holders, policy makers, health administrators, heads of rural and urban health centers and other heads of departments are all concerned about this problem. When the aforementioned recurrent services are poorly rendered, health services, educational services, transport services and other social services in the urban and rural areas of the State will be adversely affected. Urban and rural dwellers including MDA staff will also be denied of these essential services.

The following questions are raised in this study:

1) Why was the excess imprest expenditure not checked by the overhead cost budget?

2) Did environmental and policy factors have any relationship with the level of imprest expenditure?

This study will attempt to provide the answer to the above questions. The overall objective of this study is to ascertain whether or not the overhead cost budget was effectively implemented. The secondary objective is to determine whether actual imprest expenditure has any connection with the following factors: financial malpractices, special imprest, additional imprest and overhead cost control.

In order to achieve the objectives of this research and to answer the research questions posed by the problem of study, the following hypotheses will be tested:

1) Ho: There is no relationship between the overhead cost budgets of Cross River State MDAs and their imprest expenditures.

2) Ho: There is no relationship between financial malpractices in Cross River State MDAs and their imprest expenditures.

3) Ho: There is no relationship between the special imprests granted to Cross River State MDAs and their imprest expenditures.

4) Ho: There is no relationship between the additional imprests granted to Cross River State MDAs and their imprest expenditures.

5) Ho: There is no relationship between the overhead cost control procedures in Cross River State MDAs and their imprest expenditures.

\section{Review of Related Literature}

\subsection{Conceptual Framework}

This study is based on the concepts of budget, overhead cost, overhead cost budget, control and imprest which all together, make up the theory of planning and control. Budget is the quantitative expression of a plan of action (Parker, 1984; Lucey, 1988). Others view budget as a plan prepared for all business operations for the future (Adams, 2000; Awoyemi, 1989; Ola, 1982). Johnson (1992) however, sees budget as an instrument of accountability. Budget will however be ineffective without control and feedback processes. Therefore, the importance of control using budget cannot be over emphasized. Basically capital and recurrent budget make up the total budget and within the recurrent budget, we have overhead cost budget and personnel cost budget. Overhead cost is the sum of indirect material, indirect labour and indirect expenses or cost which cannot be related to an individual cost unit and so it is identified with cost classification, department or cost centre where they can be controlled. (Garbutt, 1984; Institute of Chartered Accountants of Nigeria [ICAN], 2006). Overhead 
cost is however, being considered by Adams as other charges and special expenditure. For the purpose of this study, overhead cost simply means, that portion of total recurrent expenditure that is not personnel cost. This is so defined because the two basic components of the total recurrent expenditure are personnel cost and overhead cost. Overhead cost budget which the current study is concerned with, is viewed by Adams as a budget that is prepared using previous year actual expenditure and inflation factor. Imprest which is also called standing imprest is a fixed monthly sum released by government to MDAs to service immediate government recurrent expenses for one year (Adeshoba, 2011). Occasionally, government also releases other types of imprests such as special imprest and additional imprest to MDAs. Annual imprest expenditure is basically and theoretically a function of overhead cost budget but, it is oftentimes influenced by special imprest, additional imprest and other under-the-table or unofficial considerations. Therefore, annual imprest is operationally defined as the sum of standing imprest, special imprest and additional imprest. Where control is weak, financial mal-practices such as personal and political considerations may set in and the chances of returning excess imprest funds to government treasury at year end, become very slim.

The relationships between the aforementioned variables and concepts are supported by the theory of planning and control which involves the comparison of planned expenditure with actual expenditure and the analysis of variances. According to Palmer (2012), the four key causes of budget variances are: faulty arithmetic in the budget figures, errors in the arithmetic of the actual results, wrongness of reality and differences between budget assumptions and actual outcome and comparison of budget with actual result is seen by many organizations as the end of the process. He further emphasized that there is little point in producing the variances and even less point in wasting management time discussing them if no corrective action is taken. It will also be very difficult to rely on a budget that is inaccurate. Control process is only worthwhile if the budget is realistic. Pitching variances against inaccurate budget is pointless, Palmer concluded.

\subsection{Theoretical Framework}

Administration of budgets faces a lot of challenges. One of those challenges is the absence of a clear-cut policy objectives and lack of budgetary and financial management knowledge. Not setting a standard from the onset and not appointing the right calibre of people to handle budgetary matters oftentimes lead to extra-budgetary expenditures. Examining the budgetary process of Ministry of defence in Nigeria. Omitoogun and Oduntan (2006) discovered that extra-budgetary expenditure became the order of the day due to absence of clear-cut objectives, lack of expertise, inefficient funds disbursement, improper budget analysis, inexperience and ignorance. Thus, a common cause of extra-budgetary expenditure is absence of adequate knowledge and non-setting of standards.

Even when the knowledge and standard policies are put in place, budgets can still be poorly formulated. Renzio and Smith (2005) conducted case studies which showed that expenditure framework will be ineffective when politicians are not involved in the early stages of budget formulation. They further acknowledged that the whole budget process will be undermined if politicians are not willing to be constraint either by agreed priorities or by a hard budget constraint. They concluded by saying that oftentimes, politicians are motivated by factors that are not necessarily in line with budgetary objectives.

The result of the questionnaires administered by Olurankinse (2012) suggested that experts in budget formulation were not fully involved and this lead to poor budget formulation. Still on budget formulation, exigencies not provided for, arbitrary budgetary cuts without proper investigation and releasing extra-budgetary funds to Ministries with good revenue records were responsible for the extra-budgetary expenditures in State MDAs (O. Richard, personal communication, November 20, 2012). Apart from the fact that budgets can be poorly formulated, some studies revealed that non-compliance with budgetary provisions oftentimes lead to extra-budgetary expenditures.

According to Omopariola (2002) budget is still seen by many as necessary evil that must be tolerated grudgingly. It is seen as fund-seeking instruments. He further said that the approach to budget is governmental, bureaucratic, mechanistic, incremental and non-transparent. Omopariola attributed budget failures to corrupt civil servants, pressure groups, top officials and accounting officers who influence unrealistic and unattainable proposals and see budget as an instrument for ethnic balancing. There is a correlation between overhead cost budget and extra-budgetary imprest expenditure since budget oftentimes gives rise to the creation of extra-budgetary funds which in turn encourages extra-budgetary expenditure. Allen and Radev (2010) reported that operation of extra-budgetary funds is considered by some scholars as a process that defiles sound fiscal policy, budget discipline and transparency. In the same vein, violation of financial regulations of government, non-compliance with reporting and auditing guidelines and illegal or irregular transactions will arise when secret funds are kept 
off budget ("Guide to Transparency in Public Finances: Looking Beyond the Core Budget - Extra-Budgetary Funds,"n.d.). Poor implementation of budgets in Nigeria's local government councils was due to corruption, mismanagement and failure to comply with the budget process. (Ugoh \& Ukpere, 2009).

Public sector budgets especially in the Nigerian public health system failed due to lack of fiscal discipline and role ambiguities (Allison, n.d.; Olurankinse, Yabugbe \& Ibadin, 2008). After examining the budget of Ekiti State in Nigeria, Abe (2011) found that insincerity, lack of commitments and violation of rules and regulations by officials of government made the budget ineffective. Studies carried out by Abogun and Fagbemi (2012); Aruwa (2012); Malgwi and Unegbu (2012) revealed that budgetary allocations were grossly at variance with government policy objectives and at all levels of government, there was no connection between budget and actual performance.

Insincerity oftentimes leads to financial malpractices. Funds approved and released for project execution are most times different from funds actually used. Allocations are incessantly increased without justification for such increases. In a survey conducted by Kezie-Nwoha and Agabi (2010), it was discovered that budgetary allocation increased through out the years without stipulated needs for such increases. They attributed the increase partly to inflation and partly to political reasons. Kezie-Nwoha and Agabi discovered a huge difference between money sent and money received and no clear cut reason for the huge difference was given.

What further aggravated the problem of extra-budgetary expenditure in MDAs budgets was the failure to conduct proper monitoring of budgets. Consistent budget monitoring could have instilled budget discipline and compliance but, this was either not done or was not adequately and consistently carried out. Allison (n.d) and Olurankinse (2012) in their studies revealed that reviewing, monitoring and reporting on plan and budget progress were rarely done within the three tiers of governments in Nigeria. $67.5 \%$ of the responses showed that full monitoring and implementation of the budgets were not achieved and this resulted in many uncompleted and abandoned projects.

All the studies reviewed so far, examined the causes of extra-budgetary expenditure at the Federal, State, Local Government and MDAs levels. Different issues bordering on lack of knowledge, non-setting of standards, poor formulation, non-compliance, financial malpractices and non-monitoring were all discussed. One cause of extra-budgetary expenditure which acted like a common denominator to all the studies reviewed here is budget indiscipline. All the studies agreed that budget indiscipline was one of the causes of extra-budgetary expenditure. Imprest and overhead cost control in MDAs, which both constitute important aspects of recurrent expenditure budgets were however, not considered by those studies. The current study will therefore, attempt to fill this gap by examining the possible causes of extra-budgetary expenditure in overhead cost budget (an aspect of the overall budget) which is basically used by governments at various levels to control imprest expenditure.

\section{Method}

Cross River State had 63 MDAs at the time of carrying out this study and they represented the units of analysis as well as the target population. This target population was represented by 103 accounting and audit staff. The choice of MDAs was restricted to Calabar, the Cross River State Capital. What informed this decision was the fact that majority of the MDAs are located in Calabar. Other reasons for this decision were cost reduction and time saving. The accessible population was $18 \mathrm{MDAs}$ from which a sample of 82 accounting and audit staff were randomly selected.

The sample of 82 accounting and audit staff was determined using the Yaro Yamani formula as follows:

$$
n=\frac{N}{1+N(e)^{2}}
$$

where $\mathrm{n}=$ Sample Size, $\mathrm{N}=$ Population and $\mathrm{e}=$ level of significance or error limit. Substituting with population $=103$ and significant level $=0.05$.

$$
\begin{gathered}
n=\frac{103}{1+103(0.05)^{2}} \\
\text { ie } n\left(1+103(0.05)^{2}=103\right. \\
\text { ie } n(1+103(0.0025)=103 \\
n(1+0.2575)=103 \\
n(1.2575)=103 \\
1.2575 n=103
\end{gathered}
$$




$$
\therefore n=\frac{103}{1.2575}=82
$$

\section{Sample Size $=82$}

The homogeneity of the MDAs informed the choice of the simple random sampling technique. Primary data were used for the ex-post facto research. A four-point likert scale questionnaire containing 44 structured questions was used to collect information about the six study variables isolated. The five independent variables namely, overhead cost budget, financial malpractices, special imprest, additional imprest and overhead cost control had already exerted their influences on the dependent variable (level of imprest expenditure) before the researcher got to the various MDAs. These variables could not therefore, be manipulated. Only their effects were observed and examined using questionnaire. It took the researcher one month and 3 weeks to visit and distribute 82 structured questionnaires to the 18 MDAs. Only 70 out of 82 questionnaires were returned.

The ordinal data from the questionnaire were converted to interval data by using the scores of the 4 point likert scale and these scores were eventually used to measure the dependent and independent variables. This interval data facilitated the application of multiple regression. The scores of the four-point likert scale for the six variables were allocated to all the 18 MDAs and presented in table 2 .

\subsection{Reliability}

The research problem data collected from the State Planning Commission, Calabar, were the same as the ones found at the three aforementioned major Ministries and Office of the State Accountant-General. (see table 1).

\subsection{Internal Validity}

In order to obtain a valid conclusion from the result of the study, all the scores assigned to the 5 predictor variables and 1 criterion variable, were cross-checked several times for accuracy. These independent variables were found to be suitable predictors for the criterion variable. Descriptive statistics and correlation matrix were used to test this validity. Descriptive statistics showed that the distribution of the 4-point likert scale scores generated from the primary data were moderately normal while the correlation matrix showed that all the variables have linear relationships. (see table 6).

\subsection{External Validity}

All the State MDAs have the same overhead cost budgeting and imprest systems. The conclusion derived from the result of studying the selected 18 MDAs was therefore, valid for all other MDAs not included in the study.

\subsection{Ecological Validity}

The practical relevance of the study to every day financial management practice was taken into consideration. This consideration was necessary in order to produce a result that can be useful or beneficial to all organizations facing daily and real life financial management problems.

\subsection{Model Specification}

To estimate the determinants of the level of imprest expenditure of the MDAs, the multiple regression analysis was used. The model is implicitly stated as:

$Y_{1}=f\left(x_{1}, x_{2}, x_{3}, x_{4}, x_{5}\right)$ where,

$Y_{1}=$ Level of Imprest Expenditure (LOIE)

$x_{1}=$ Overhead Cost Budget $(\mathrm{OHCB})$

$x_{2}=$ Financial Malpractices (FINM

$x_{3}=$ Special Imprest (SIMP)

$x_{4}=$ Additional Imprest $($ AIMP)

$x_{5}=$ Overhead Cost Control (OHCC)

In order to select the lead equation for each location, four functional forms were tried as follows:

$$
\begin{aligned}
& \text { i. Linear } \rightarrow Y_{1}=b_{0}+b_{1} x_{1}+b_{2} x_{2}+b_{3} x_{3}+b_{4} x_{4}+b_{5} x_{5}+e \\
& \text { ii. Exponential } \rightarrow Y_{1}=\operatorname{In} Y_{1}+b_{0}+b_{1} x_{1}+b_{2} x_{2}+b_{3} x_{3}+b_{4} x_{4}+b_{5} x_{5}+e \\
& \text { iii. Semi-logarithmic } \rightarrow Y_{1}=\operatorname{In} b_{0}+b_{1} \operatorname{In} x_{1}+b_{2} \operatorname{In} x_{2}+b_{3} \operatorname{In} x_{3}+b_{4} \operatorname{In} x_{4}+b_{5} \operatorname{In} x_{5}+e \\
& \text { iv.Double logarithmic } \rightarrow Y_{1}=\operatorname{In} Y_{1}+\operatorname{In} b_{0}+b_{1} \operatorname{In} x_{1}+b_{2} \operatorname{In} x_{2}+b_{3} \operatorname{In} x_{3}+b_{4} \operatorname{In} x_{4}+b_{5} \operatorname{In} x_{5}+e
\end{aligned}
$$

The lead equation is determined by the following criteria: conformity of the signs of the regression co-efficients 
with economic theory, coefficient of multiple determination $\left(\mathrm{R}^{2}\right)$, Significance of the model through F-test and the co-efficients of the independent variables through the F-test. The lead equation therefore fell on:

$$
\begin{gathered}
\text { i. Linear } \rightarrow Y_{1}=b_{0}+b_{1} x_{1}+b_{2} x_{2}+b_{3} x_{3}+b_{4} x_{4}+b_{5} x_{5}+e \\
\text { i.e } \operatorname{LOIE}_{1}=b_{0}+b_{1} \text { OHCB }+b_{2} \text { FINM }+b_{3} \text { SIMP }+b_{4} A I M P+b_{5} \text { OHCC }+e
\end{gathered}
$$

\section{Results}

\subsection{The Demographic, Educational and Career Status of Sample Members}

The results show the demographic, educational and career status of sample members in table 3 . The participants in this ex-post facto survey were talented, knowledgeable and experienced to respond to the 44 likert scale items in the structured questionnaire. 20 respondents who filled in and returned their questionnaires were females representing $29 \%$ while 50 representing $71 \%$ were males. This presupposes that the MDAs were male dominated and this helped in invigorating the females to work hard towards the attainment of common goal of accurately controlling the imprest and overhead costs. The table also shows the age brackets of the respondents as those between 30-40 years (20) representing 29\%, $41-51$ years (27) representing 37\% and 52-62 years (13) indicating $19 \%$. This shows that respondents were all adults with matured minds and good faculties. Respondents were also categorized according to their levels of management with 14 members of the top management representing $20 \%$, middle management (55) representing $79 \%$ and only 1 member in the operational management level representing $1 \%$, implying that imprest and overhead cost control duties were not properly segregated to facilitate internal check and internal control. On the categorization of respondents according to staff cadre, accounting staff members were 50 representing $71 \%$ while 20 were audit staff representing $29 \%$. This implies that majority of the respondents had good working knowledge of the questions asked. The survey results in table 4 also revealed the categorization of respondents by highest qualification as follows: WASC/SSCE (secondary) 5 representing 7\%, Diploma 17 representing 24\%, Degree 28 representing 40\% and Professional 17 indicating 24\%. This shows that majority of the respondents were highly qualified academically to answer all the questions accurately. In all, the survey result in table 3 revealed high response rates for all the categories of respondents.

\subsection{Overhead Cost Budgeting}

Table 5 shows that $54 \%$ (sum of agree and strongly agree) of the respondents agreed that Imprest is influenced by factors other than by overhead cost budget while overhead cost budget does not provide for unexpected increases in staff size, depts, HODs, activities, prices and inflation. This revelation will be used to answer research question 1 in order to explain the reason why the excess imprest expenditure was not checked by the overhead cost budget. The table also shows that $51 \%$ of the respondents disagreed with the statement that special imprest is received and is based on unofficial factors and it also compliments the overhead cost budget. Research question $2 \mathrm{a}$ will be answered using this revelation. On the question of whether a relationship exist between the granting of additional imprest and annual imprest expenditure, the table further revealed that $68 \%$ of the respondents disagreed with the statement that additional imprest is received and is based on unofficial factors and it also compliments the overhead cost budget. Research question $2 \mathrm{~b}$ will be answered using this revelation. On the extent to which imprest fund providers have carried out effective and efficient budget monitoring activities and cash control procedures, $65 \%$ of the respondents disagreed with the statement that efficient and effective budget monitoring activities and cash control procedures are not carried out by imprest fund providers. This revelation will be used to answer research question $2 \mathrm{c}$. Table 5 further revealed that $72 \%$ of the respondents disagreed with the statement that annual imprest expenditure is influenced by political considerations, god-fatherism, ethnic considerations, personal interest, deliberate arithmetical errors and sometimes forged bills. Research question $2 \mathrm{~d}$ will be answered using this revelation.

\subsection{Descriptive Statistics}

Table 6 , concerning descriptive statistics, showed a moderately high variability between the means and standard deviations of all the study variables suggesting that the distribution of the 4-point likert scale scores generated from the primary data were moderately normal. The correlation matrix table in table 6 indicated that the degrees of correlation between the variables were very high and significant at the alpha level of 0.01 (2-tailed) suggesting high linear relationships among the six variables. These results from descriptive statistics and correlation matrix provided the foundation for the multiple regression analysis.

\subsection{Regression Analysis}

The multiple regression output of table 6 indicated that the joint contribution of the independent variables was very high while the linear relationship among the variables was highly significant. $\left(R^{2}=.99, F(5,12)=\right.$ $305.27, \mathrm{p}<.01)$. 
The expected value (the constant or intercept) of the criterion variable (LOIE) when the predictor variables equal to zero, was positive but, was not significant $\left(\beta_{0}=.83, n . s\right)$.

\subsection{Hypotheses Testing}

Five null hypotheses as stated in section one were tested:

Hypothesis 1: There is no relationship between the overhead cost budgets of Cross River State MDAs and their imprest expenditures. This was supported by a non-significant and weak positive correlation coefficient $\left(\beta_{1}=.29, n . s\right)$. This was also supported by $54 \%$ (both agree and strongly agree) of the respondents who agreed that imprest was influenced by factors other than by overhead cost budget. Please see tables 5 and 6 respectively. Despite the fact that the positive correlation coefficient of .29 was not significant relative to the alpha level of .05 , it was only approaching significance since its p-value was less than .10. The null hypothesis was therefore accepted while the alternative was rejected.

Hypothesis 2: There is no relationship between financial malpractices in Cross River State MDAs and their imprest expenditures. This was also supported by a non-significant and very low negative correlation coefficient $\left(\beta_{2}=-.04, n . s\right)$. This was supported by $72 \%$ of the total respondents (see tables 5 and 6 ). The null hypothesis was therefore, accepted while the alternative was rejected.

Hypothesis 3: There is no relationship between the special imprests granted to Cross River State MDAs and their imprest expenditures. This was supported by a non-significant and weak positive correlation coefficient $\left(\beta_{3}=.28, n . s\right) .51 \%$ of the respondents also supported this result. Please see tables 5 and 6 . The null hypothesis was therefore, accepted while the alternative was rejected.

Hypothesis 4: There is no relationship between the additional imprests granted to Cross River State MDAs and their imprest expenditures. This was supported by a non-significant and very low negative correlation coefficient $\left.\beta_{4}=-.07, n . s\right) .68 \%$ of the total respondents supported this result. Please see tables 5 and 6 . The null hypothesis was therefore, accepted while the alternative was rejected.

Hypothesis 5: There is no relationship between the overhead cost control procedures of Cross River State MDAs and their imprest expenditures. This hypothesis was not supported. The regression result showed that there was a positive and significant relationship between overhead cost control and the level of imprest expenditure. $\left(\beta_{5}=.46, p<.05\right)$. This regression result was supported by $65 \%$ of the total respondents. Please see tables 5 and 6 . The null hypothesis was therefore, rejected while the alternative hypothesis was accepted.

\section{Discussion}

Hypothesis 1: There is a positive relationship between the overhead cost budgets of Cross River State MDAs and their imprest expenditures but, it is weak and not significant. $\left(\beta_{1}=.29, n . s\right)$. What this positive relationship means is that an upward review of overhead cost budget can be used to predict an increase in the level of imprest expenditure. However, overhead cost budget has a weak relationship with the level of imprest expenditure. The relationship is also not significant due to the effects of other factors that will be revealed later. This correlation was however, not significant relative to the alpha level of .05. But, its p-value was less than .10 as it was approaching significance. (see table 6). Approaching significance only suggests that the reason why imprest is granted to MDAs is because of the existence of overhead cost budget. In general, the relationship was not significant. 54\% of all the respondents agreed (agree; strongly agree) that the overhead cost budget did not make provision for exigencies. Please see table 5. The factors responsible for extra-budgetary imprest expenditures in State MDAs were: exigencies paid for but, not included in the overhead cost budget, arbitrary budgetary cuts without proper investigation and releasing extra-budgetary imprest funds to government establishments with impressive revenue records (please refer to para. 3 of literature review). The aforementioned regression and empirical results were used to answer research question 1 in section one which is now restated as: Why was the excess imprest expenditure not checked by the overhead cost budget? Imprest funds were released to cater for exigencies without revising the overhead cost budget. Overhead cost budget was therefore, inaccurate and badly formulated. This finding was consistent with the works of Omitoogun and Oduntan (2006); Renzio and Smith (2005) where it was discovered that common causes of extra-budgetary expenditure were the absence of adequate financial management knowledge, non-setting of standards and poor budget formulation. How then does one comply with a budget that did not make provisions for exigencies? A budget that was subjected to arbitrary cuts and a budget that did not make special provision for establishments with high revenue records. The abandonment of such a budget will absolutely lead to extra-budgetary expenditures. Inaccuracies in the budget therefore, lead to non compliance and this made the level of imprest expenditure to rise above the budget. This finding is consistent with the works of Omopariola (2002) and Ugoh and Ukpere (2009) where the failure to 
comply with budgetary provisions was discovered as one of the causes of extra-budgetary expenditures.

Hypothesis 2: There is a negative relationship between financial malpractices in Cross River State MDAs and their imprest expenditures but, it is very weak and not significant $\left(\beta_{2}=-.04, n . s\right)$. What this negative relationship means is that as the level of financial malpractices rise, the imprest funds meant for running the MDAs falls. This negative relationship is however very weak suggesting that financial malpractices have little or no association with the level of imprest expenditure. The relationship is not significant due to the effects of factors already revealed by the testing of the first hypothesis. The responses of $72 \%$ of all the respondents further supported this result (see table 5). These results were used to answer research question $2 \mathrm{~d}$ in section one which is now represented as: did environmental factors have any relationship with the level of imprest expenditure? These findings are not consistent with the works of Omopariola (2002), Ugoh and Ukpere (2009) and Kezie-Nwoha and Agabi (2010) where budget failures were attributed to corrupt civil servants, general corruption, mismanagement, pressure groups, top officials and accounting officers who influenced unrealistic and unattainable proposals. The contribution of the current study to the existing literature is that even though financial malpractices had strong associations with extra-budgetary expenditures in the three tiers of government they have little or no associations with extra-budgetary imprest expenditures in Cross River State MDAs. This inconsistency should further be verified by extending the current study to other States and Local Governments in Nigeria. Inaccuracies in the overhead cost budgets of Cross River State MDAs were associated with the extra-budgetary imprest expenditures.

Hypothesis 3: There is a positive relationship between the special imprests granted to Cross River State MDAs and their imprest expenditures but, it is weak and is not significant $\left(\beta_{3}=.28, n . s\right)$ What this positive relationship means is that the more special imprest is granted to MDAs, the stronger the overhead cost budget in facilitating the release of imprest funds for exigencies not previously included in the budget. This positive relationship is however, weak and is not significant due to factors already revealed by the testing of the first hypothesis. Special imprest is granted to cater for expenditures that exceed the conventional or standing imprest. The results showed that special imprest could not also check exigencies. $51 \%$ of all the respondents disagreed (strongly disagree and disagree) that special imprest is received and it complements the overhead cost budget (see table 5). Therefore, special imprest was ineffectively used in correcting the inadequacies of the overhead cost budget. These results were used to answer research question 2a in section one which is now represented as: did policy factors have any relationship with the level of imprest expenditure? This finding is also consistent with the findings of Omitoogun and Oduntan (2006); Renzio and Smith (2005) as disclosed in hypothesis 1 above.

Hypothesis 4: There is a negative relationship between the additional imprests granted to Cross River State MDAs and their imprest expenditures but, it is very weak and is not $\operatorname{significant}\left(\beta_{4}=-.07, n . s\right)$ What this negative relationship means is that the higher the delay in releasing additional imprest, the weaker the overhead cost budget in facilitating the release of imprest funds for exigencies not previously included in the overhead cost budget. This negative relationship is however very weak suggesting that additional imprest has little or no association with the level of imprest expenditure. The relationship is not significant due to the effects of factors already revealed by the testing of the first hypothesis. Additional imprest is used to compliment overhead cost budget and should therefore be useful in checking exigencies not provided for in overhead cost budget. The results showed that additional imprest could not also check exigencies. $68 \%$ of all the respondents disagreed (strongly disagree and disagree) that additional imprest is received and it also compliments overhead cost budget in checking exigencies. Only 16 out of all the 70 respondents said that their organizations received additional imprest. (see table 5). Additional imprest was therefore, ineffectively used in correcting the inadequacies of the overhead cost budget. This result was used to answer research question $2 b$ in section one which is now restated as: did policy factors have any relationship with the level of imprest expenditure? This finding is consistent with the aforementioned works of Omitoogun and Oduntan (2006); Renzio and Smith (2005) as disclosed in hypothesis 1 above.

Hypothesis 5: There is a positive relationship between the overhead cost control procedures of Cross River State MDAs and their imprest expenditures and is significant but, it is weak. $\left(\beta_{5}=.46, p<.05\right)$ What this positive relationship means is that as the overhead cost control and cash control procedures get tighter and tougher, the efficiency and effectiveness in the use of the imprest fund increases. But, the size of the correlation coefficient indicates a weak connection between overhead cost control and level of imprest expenditure. The relationship is significant because there is existence of control even though it is not very effective. $65 \%$ of all the respondents disagreed (strongly disagree and disagree) with the general statement that monitoring and cash control procedures are not carried out (please see table 5). These results were used to answer research question $2 \mathrm{c}$ in 
section one which is now restated as: did policy factors have any relationship with the level of imprest expenditure? This finding is not consistent with the works of Allison (n.d.) and Olurankinse (2012) who revealed in their studies that reviewing, monitoring and reporting on plan and budget progress were rarely done within the three tiers of governments in Nigeria. $67.5 \%$ of the responses showed that full monitoring and implementation of budgets were not achieved. The contribution of the current study to the existing literature is that even though poor budget monitoring activities had strong associations with extra-budgetary expenditures in the three tiers of government, they have weak associations with extra-budgetary imprest expenditures in Cross River State MDAs. This inconsistency should further be verified by extending the current study to other States and Local Governments in Nigeria. Inaccuracies in the overhead cost budgets of Cross River State MDAs were associated with the extra-budgetary imprest expenditures.

\section{Summary, Conclusion and Recommendations}

The use of overhead cost budgets, special imprests and additional imprests was ineffective. Financial malpractices had little or no association with the excess imprest expenditure while the existing budgetary control was weak. Lack of budgetary provisions for exigencies gave rise to non-compliance with the existing overhead cost budgeting system. This non-compliance eventually lead to governmental actions like paying for exigencies and releasing extra-budgetary imprest funds to viable MDAs without revising the existing overhead cost budget. These governmental actions as revealed by the findings therefore, had strong associations with the excess of imprest expenditure over the overhead cost budget. Efficient and effective overhead cost budgeting system and regular budget review can help check extra-budgetary imprest expenditures. The best budget is that which depends on the exigencies of the time. Finally, adequate knowledge, integrity, and the desire to change a problem situation can make even the worst budget to work well. It was in this same vein that Gilbert (2000) said: "We need a vision of improvement and change - how to keep moving forward, how to know when we are making mistakes and how to correct them." This study should be extended to MDAs of other States and local governments in Nigeria.

\section{Acknowledgements}

The assistance of all the Heads and Staff of Accounts and Audit departments of the 18 MDAs selected for the study is highly acknowledged. My sincere gratitude also goes to the Cross River State Planning Commission, Calabar for providing useful research materials.

\section{References}

Abe, T. (2011). Fiscal responsibility, accountability and democratic consolidation in Nigeria The case of Ekiti State. European Journal of Economics, Finance and Administrative Sciences, 37. Retrieved from http://www.eurojournals.com

Abogun, S., \& Fagbemi, T. O. (2012). The efficacy of budgeting as a control measure in developing economies: A study from Nigeria. Asian Social Science, 8(1), 176.

Adams, R. A. (2000). Public sector accounting and finance (1st ed.). Lagos, Nigeria: Corporate Publishers Ventures.

Adeshoba, J. A. (2011). Internal audit procedures and operations challenges and initiatives. Retrieved from http://www.bulletin.oquife.edu.ng/download/11-internal-audit-procedures-and-operations-challenges

AllAfrica.com. (2012). Travel imprest fraud - Govt move welcome 2012. Retrieved from http://www..allafrica.com/stories/201210051228.html

Allen, R., \& Radev, D. (2010). Technical notes and manuals-Extra-budgetary funds. IMF Affairs Department. Retrieved from http://www.imf.org/external/pubs/ft/tnm/2010/tnm1009.pdf

Allison, C. (n.d.). Strengthening planning and budgeting at State level, Nigeria. Partnership for Transforming Health Systems (PATHS). $\quad$ Retrieved from http://www.hisp.org/portals/7/resources/PATHS-TechBrief-Planningbudgeting.pdf

Ameh, J. (2012, December 2). N’Assembly, MDAs misappropriated N21.1bn Reps Committee. The Punch Newspaper. $\quad$ Retrieved http://www.punching.com/news/nassembly-mdas-misappropriated-n21-1bn-reps-committee/

Aruwa, S. A. S. (2012). Nigerian budgeting process and the magnitude of budget variances. Retrieved from http://www.academia.edu/222415/NIGERIAN-BUDGETING-PROCESS-AND-THE-MAGNITUDE-OF-B UDGET-VARIANCES 
Awoyemi, E. O. (1989). A guide to government accounting and internal audit (1st ed.). Ibadan, Nigeria: Onibonoje Press.

Garbutt, D. (1984). Carter's advanced accounts: A manual of book-keeping and accountancy for students (7th ed.). Great Britain: Pitman Publishing Limited.

Gilbert, S. W. (2000). A new vision worth working toward - Connected education and collabo-rative change. Retrieved from http://www.titgroup.org/gilbert/NewVwwt2000-2-14-00.htm

Government to recover unretired imprest from the salaries of Public Officers found guilty. (2012, October 20). Lusaka Times. Tetrieved from http://www.lusakatimes.com/2012/10/20/government-recover-unretired-imprest-salaries-public

Guide to transparency in public finances: Looking beyond the core budget - Extra-budgetaryfunds. (n.d.). Retrieved http://www.internationalbudget.org/WP-content/uploads/looking-beyond-the-core-budget-1-Extra-budgetar y-Funds

Hansen, S. C., Otley, D. T., \& Van der Stede, W. A. (2003). Practice developments in budgeting: An overview and research perspective. Journal of Management Accounting Research, 15, 95-116. http://dx.doi.org/10.2308/jmar.2003.15.1.95

Institute of Chartered Accountants of Nigeria. (2006). ICAN study pack on professional examination II: Public sector accounting and finance. Nigeria: VI Publishing Limited.

Johnson, I. E. (1992). Public sector accounting and financial control (1st ed.). Ilupeju, Nigeria: Speed Setters Nigeria Limited.

Kezie-Nwoha, H., \& Agabi, D. M. (2010). Tracking government resource allocation to schools in Nigeria: Abantu for development funded by Result for Development. Retrieved from http:/tap.resultsfordevelopment.org/sites/tap.resultsfordevelopment.org/files/resources/A

Lucey, T. (1988). Costing: An instructional manual (2nd ed.). Great Britain: English Language Book Society/DP Publication.

Malgwi, A. A., \& Unegbu, A. O. (2012). Budget in Nigerian public sector: Need for balanced scrorecard perspective. International Journal of Finance and Accounting, 1(2), 1-6. http://dx.doi.org/10.5923/j.ijfa.20120102.01

Norton, A., \& Elson, D. (2002). What is behind the budget? Politics, rights and accountability in the budget process. Overseas Development Institute, London. Retrieved from http://www.gsdrc.org/go/display/document/legacyid/402

Ola, C. S. (1982). Management accounting: Theory and application (1st ed.). United Kingdom, UK: Graham Burn.

Olatunji, J. S., \& Daniel, K. (2012, July 5). Extra-budgetary spending: finance, police affairs, Ministries, others risk Reps hammer. Nigerian Tribune. Retrieved from http://www.Tribune.com.ng/index.php/news/43545-extra-budgetary-spending-finance-police-affairs-Ministr ies-others-risk-reps-hammer

Olurankinse, F. (2012). Due process and budget implementation: An evaluation of Nigerian Public sector auditing. Asian Journal of Finance and Accounting, 4(2), 144-154.

Olurankinse, F., Yabugbe, P. O., \& Ibadin, L. A. (2008). Budgeting as a tool for control and Performance evaluation in the public sector. Journal of Research in National Development, 6(2), 1-9. Retrieved from http://www.transcampus.org/JORINDV6Dec2008/JournalsV6NO2Dec20085.html

Omitoogun, W., \& Oduntan, T. (2006). Budgeting for the military sector in Africa: The processes and mechanisms of control. Retrieved from http://www.ssrnetwork.net/document_library/detail/4257/Budgeting-for-the-military-sector-in-africa-the-pr ocesses-and-mechanisms-of-control-nigeria

Omopariola, O. (2002). Nigeria's financial management nightmare. Retrieved from http://www.nuc.edu.ng/nucsite/file/ILS\%202002/ILS-64.pdf

Palmer, D. A. (2012). Budgetary control and variance analysis: Guides for financial management development. Retrieved from http://www.FinancialManagmentDevelopment.com 
Parker, R. H. (1984). Macmillan dictionary of accounting (1st ed.). Great Britain: Anchor Brendon Limited.

Renzio, P., \& Smith, S. (2005). Linking policies and budgets: Implementing medium term expenditure frameworks in a PRSP context. Retrieved from http://www.odi.org.uk

Tanzania Corruption Tracker System. (2012). Squandered, unretired Tz Govt imprest equals Half national budget 2012.

Retrieved

from

http://www.corruptiontracker.or.tz/dev/index.php?option=com=content\&task=view\&id=42\&ite...2012

Ugoh, S. C., \& Ukpere, W. I. (2009). Problems and prospects of budgeting and budget implementation in Local Government System in Nigeria. African Journal of Business Management, 3(12), 836-846.

Umoru, H., \& Shaibu, I. (2012, January 20). Senate bars FG from extra-budgetary spending Vanguard. Retrieved from http://www.Vanguardngr.com/2012/01/subsidy-senate-bar-fg-From-extra-budgetary-spending/

Wehner, J. (2006). Assessing the power of the purse: An index of legislative budget institutions. Political Studies, 54, 767-785. http://dx.doi.org/10.1111/j.1467-9248.2006.00628.x

Yovbi, M. (2007, February 13). The civil servant and his imprest. Nigerian Village Square. Retrieved from http://www.nigeriavillagesquare.com/articles/from-the-homefront/the-civil-servant-and-his-imprest

\section{Appendix}

Table 1. The level of imprest expenditure between 2007 and 2011

(Overhead cost budget vesus actual imprest expenditure of three major ministries in cross river state, Nigeria)

\begin{tabular}{|c|c|c|c|}
\hline Ministry/Year & Approved Overhead & Actual Imprest & Variance \\
\hline & Cost Budget & Expenditure & Adverse $=(-)$; Favourable $=(+)$ \\
\hline Moh, Calabar & $\#$ & $\#$ & \# \\
\hline 2007 & $14,100,000$ & $78,579,362$ & $-64,479,362$ \\
\hline 2008 & $27,703,626$ & $2,073,827,114$ & $-2,046,123,488$ \\
\hline 2009 & $40,490,551$ & $1,684,859,993$ & $-1,644,369,442$ \\
\hline 2010 & $36,975,600$ & $32,401,380$ & $4,574,220$ \\
\hline 2011 & $40,708,391$ & $29,209,166$ & $11,499,225$ \\
\hline Total & $159,978,169$ & $3,898,877,015$ & $-3,738,898,847$ \\
\hline Average & $31,995,634$ & $779,775,403$ & $-747,779,769$ \\
\hline \multicolumn{4}{|l|}{ Moe, Calabar } \\
\hline 2007 & $9,600,000$ & $4,800,000$ & $4,800,000$ \\
\hline 2008 & $9,775,000$ & $197,148,804$ & $-187,373,804$ \\
\hline 2009 & $14,478,650$ & $9,400,080$ & $5,078,570$ \\
\hline 2010 & $12,000,000$ & $9,600,000$ & $2,400,000$ \\
\hline 2011 & $12,002,990$ & $5,126,668$ & $6,876,321$ \\
\hline Total & $57,856,640$ & $226,075,553$ & $-168,218,913$ \\
\hline Average & $11,571,328$ & $45,215,111$ & $-33,643,783$ \\
\hline \multicolumn{4}{|l|}{ Mow, Calabar } \\
\hline 2007 & $7,200,000$ & $3,600,000$ & $3,600,000$ \\
\hline 2008 & $171,595,418$ & $311,806,090$ & $-140,210,672$ \\
\hline 2009 & $85,205,108$ & $227,678,477$ & $-142,473,369$ \\
\hline 2010 & $261,456,480$ & $105,921,477$ & $155,535,003$ \\
\hline 2011 & $261,591,432$ & $220,475,500$ & $41,115,932$ \\
\hline Total & $787,048,438$ & $869,481,545$ & $-82,433,107$ \\
\hline Average & $157,409,688$ & $173,896,309$ & $-16,486,621$ \\
\hline
\end{tabular}

Source: State Planning Commission, Calabar, Cross River State. 
Table 2. Distribution of scores of dependent and independent variables by MDAs

\begin{tabular}{|c|c|c|c|c|c|c|}
\hline Ministries, Departments And Agencies & $\begin{array}{l}\text { Ohcb } \\
\mathrm{X}_{1} \\
\end{array}$ & $\begin{array}{l}\text { Finm } \\
X_{2} \\
\end{array}$ & $\begin{array}{l}\text { Simp } \\
\mathbf{X}_{3} \\
\end{array}$ & $\begin{array}{l}\text { Aimp } \\
\mathbf{X}_{4} \\
\end{array}$ & $\begin{array}{l}\text { Ohce } \\
\mathbf{X}_{5} \\
\end{array}$ & $\begin{array}{l}\text { Loie } \\
\mathbf{Y} \\
\end{array}$ \\
\hline 1. Ministry Of Health Headquarters, Calabar. & 94 & 82 & 37 & 31 & 96 & 74 \\
\hline 2. Ministry Of Works Headquarters, Calabar & 99 & 89 & 42 & 36 & 106 & 88 \\
\hline 3. Ministry Of Education Headquarters, Calabar. & 56 & 32 & 22 & 18 & 38 & 32 \\
\hline 4. Ministry Of Justice, Calabar. & 84 & 64 & 32 & 27 & 72 & 64 \\
\hline 5. Ministry Of Finance, Calabar. & 61 & 55 & 24 & 24 & 59 & 52 \\
\hline 6. Ministry Of Women Affairs, Calabar. & 90 & 73 & 31 & 31 & 69 & 65 \\
\hline 7. Ministry Of Local Government Affairs, Calabar. & 141 & 136 & 60 & 44 & 122 & 108 \\
\hline 8. Ministry Of Social Development, Calabar. & 79 & 94 & 33 & 33 & 90 & 68 \\
\hline 9. Ministry Of Lands And Survey, Calabar. & 44 & 34 & 13 & 16 & 37 & 29 \\
\hline 10. Office Of The Auditor-General For State Govt., Cal. & 210 & 204 & 83 & 77 & 202 & 160 \\
\hline 11. Office Of The Auditor-General For Local Govt., Cal. & 102 & 75 & 31 & 29 & 90 & 77 \\
\hline 12. State Electrification Agency, Calabar. & 69 & 73 & 28 & 25 & 69 & 62 \\
\hline 13. Internal Revenue Service, Calabar. & 35 & 39 & 16 & 9 & 34 & 28 \\
\hline 14. Department Of Public Transportation, Calabar. & 33 & 33 & 14 & 16 & 35 & 30 \\
\hline 15. Political And Legal Affairs, Calabar & 18 & 16 & 8 & 8 & 20 & 14 \\
\hline 16. Office Of The Secretary To The State Govt., Calabar. & 44 & 20 & 15 & 15 & 28 & 32 \\
\hline 17. Debt Management, Calabar. & 18 & 16 & 6 & 5 & 18 & 12 \\
\hline 18. Joint Account Allocation Committee, Calabar. & 20 & 24 & 8 & 8 & 21 & 15 \\
\hline
\end{tabular}

Source: Field Survey.

Table 3. Population, sample and response rate of each group

\begin{tabular}{|c|c|c|c|c|c|}
\hline & POPULATION & & SAMPLE & RESPONSE & RESPONSE RATE \\
\hline \multicolumn{6}{|l|}{ GENDER: } \\
\hline Male & $73(71 \%)$ & & 58 & 50 & $86 \%$ \\
\hline Female & $30(29 \%)$ & $100 \%$ & 24 & 20 & $83 \%$ \\
\hline \multicolumn{6}{|l|}{ STAFF CATEGORY: } \\
\hline Top Management & $21(20 \%)$ & & 16 & 14 & $88 \%$ \\
\hline Middle Management & $81(79 \%)$ & & 65 & 55 & $85 \%$ \\
\hline Operational Management & $1(1 \%)$ & $100 \%$ & 1 & 1 & $100 \%$ \\
\hline \multicolumn{6}{|l|}{ STAFF CADRE: } \\
\hline Accounting & $73(71 \%)$ & & 58 & 50 & $86 \%$ \\
\hline Auditing & $30(29 \%)$ & $100 \%$ & 24 & 20 & $83 \%$ \\
\hline TOTAL & 103 & & 82 & 70 & $85 \%$ \\
\hline
\end{tabular}

Table 4. Biographical data of respondents

\begin{tabular}{lll}
\hline Variable & Frequency & Percent \\
\hline Gender: & 50 & $71 \%$ \\
Male & 20 & $29 \%$ \\
Female & & \\
\hline Age: & 20 & $29 \%$ \\
$30-40$ & 27 & $37 \%$ \\
$41-51$ & 13 (Missing =10) & $19 \%$ \\
$52-62$ & & $20 \%$ \\
\hline Staff Catergory: & 14 & $79 \%$ \\
Top Management & 55 & $1 \%$ \\
Middle Management & 1 & $71 \%$ \\
Operational Management & & $29 \%$ \\
\hline Staff Cadre: & 50 & \\
Accounting & 20 & $7 \%$ \\
Auditing & & $24 \%$ \\
Highest Qualification: & 5 & $40 \%$ \\
Wasc/Ssce (Secondary) & 17 & $24 \%$ \\
Diploma & 28 & \\
Degree & 17 (Missing = 3) & \\
Professional & & \\
\hline
\end{tabular}


Table 5. Analysed responses on reasons for extra-budgetary imprest expenditure

\begin{tabular}{|c|c|c|c|c|c|c|}
\hline $\begin{array}{l}\text { Code } \\
\text { No }\end{array}$ & $\begin{array}{l}\text { Statements Relating To The Research Question 1: Why Was The Excess } \\
\text { Imprest Expenditure Not Checked By The Overhead Cost Budget? }\end{array}$ & Sd & D & A & Sa & Total \\
\hline & Overhead Cost Budget And Imprest Expenditure & & & & & \\
\hline 10 & Annual Imprest Is Derived From Annual Overhead Cost Budget & 3 & 11 & 30 & 26 & \\
\hline 11 & Increase In Annual Imprest Is Due To Increase In Overhead Cost Budget & 4 & 18 & 31 & 17 & \\
\hline 12 & Unofficial Factors Can Also Affect Annual Imprest & 14 & 28 & 19 & 9 & \\
\hline 13 & Imprest Can Be Increased Without Increasing Overhead Cost Budget & 30 & 21 & 13 & 6 & \\
\hline 14 & In My Ministry, Annual Imprest Sometimes Exceeds Overhead Cost Budget & 34 & 26 & 8 & 2 & \\
\hline 15 & In My Ministry, Annual Imprest Increases As Overhead Cost Budget Increases & 9 & 23 & 28 & 10 & \\
\hline 16 & Oftentimes, Imprest Approval Is Not Based On Overhead Cost Budget & 12 & 26 & 25 & 7 & \\
\hline 17 & Overhead Cost Budget Does Not Provide For Unexpected Increase In Staff Size & 12 & 16 & 26 & 16 & \\
\hline 18 & Overhead Cost Budget Does Not Provide For Unexpected Increase In Depts. & 10 & 14 & 38 & 8 & \\
\hline 19 & Overhead Cost Budget Does Not Provide For Inflation & 8 & 17 & 34 & 11 & \\
\hline 20 & Overhead Cost Budget Does Not Provide For Unexpected Increase In Hods & 5 & 13 & 40 & 12 & \\
\hline 21 & Overhead Cost Budget Does Not Provide For Unexpected Increase In Activities & 6 & 25 & 30 & 9 & \\
\hline \multirow[t]{3}{*}{22} & Overhead Cost Budget Does Not Provide For Unexpected Increase In Prices & 7 & 20 & 27 & 16 & \\
\hline & Total Frequencies Of Responses For The General Statement & 154 & 258 & 349 & 149 & 910 \\
\hline & Total Frequencies Of Responses For The General Statement In Percentages & $17 \%$ & $28 \%$ & $38 \%$ & $16 \%$ & $100 \%$ \\
\hline
\end{tabular}

Statements Relating To Research Question 2: Did Environmental And Policy Factors Have Any Relationship With The Level Of Imprest Expenditure?

\section{Special Imprest And Imprest Expenditure (A)}

23 My Ministry Usually Receives Special Imprest

24 Special Imprest Is Oftentimes Based On Other Unofficial Factors

25 Special Imprest Compliments The Overhead Cost Budget

Total Frequencies Of Responses For Special Imprest

Total Frequencies Of Responses For Special Imprest In Percentages

Additional Imprest And Imprest Expenditure (B)

My Ministry Usually Receives Additional Imprest

Additional Imprest Is Oftentimes Based On Unofficial Factors

Additional Imprest Compliments The Overhead Cost Budget

Total Frequencies Of Responses For Additional Imprest

Total Frequencies Of Responses For Additional Imprest In Percentages

Overhead Cost Control And Imprest Expenditure (C)

29 My Ministry'S Annual Imprest Is Usually Supported By Warrant.

$30 \quad$ Not All Imprest Warrants Are Based On Overhead Cost Budget.

31 My Ministry'S, Overhead Cost Is Not Controlled.

Imprest Warrant S Of My Ministry Are Not Supported By Overhead Cost Budget.

Vote Can Be Increased Without Adjusting Overhead Cost Budget.

Wrongly Verified Imprest Vouchers Are Oftentimes Re-Imbursed.

Sometimes, Departmental Vote Books Are Not Maintained.

Sometimes, Cash Control Procedures Are Not Complied With.

Total Frequencies Of Responses For Overhead Cost Control

Total Frequencies Of Responses For Overhead Cost Control In Percentages

Financial Malpractices And Imprest Expenditure (D)

37 Political Considerations Increase Annual Imprests

38 Political Considerations Decrease Annual Imprests

39 God-Fatherism Increases Annual Imprests

40 Ethnic Considerations Increase Annual Imprests

41 Ethnic Considerations Decrease Annual Imprests

42 Personal Interest Increases Annual Imprests

43 Imprest Vouchers With Deliberate Arithmetical Errors Are Paid

44 Sometimes, Forged Bills For Imprest Re-Imbursement Are Settled.

Total Frequencies Of Responses For Financial Malpractices

Total Frequencies Of Responses For Financial Malpractices In Percentages

\begin{tabular}{|c|c|c|c|c|}
\hline Sd & D & A & Sa & Total \\
\hline 16 & 11 & 34 & 9 & \\
\hline 17 & 28 & 19 & 6 & \\
\hline 13 & 22 & 24 & 11 & \\
\hline 46 & 61 & 77 & 26 & 210 \\
\hline $22 \%$ & $29 \%$ & $37 \%$ & $12 \%$ & $100 \%$ \\
\hline Sd & D & $\mathbf{A}$ & $\mathrm{Sa}$ & Total \\
\hline 18 & 36 & 12 & 4 & \\
\hline 16 & 40 & 13 & 1 & \\
\hline 11 & 22 & 32 & 5 & \\
\hline 45 & 98 & 57 & 10 & 210 \\
\hline $21 \%$ & $47 \%$ & $27 \%$ & $5 \%$ & $100 \%$ \\
\hline Sd & D & $\mathbf{A}$ & $\mathbf{S a}$ & Total \\
\hline 1 & 6 & 33 & 30 & \\
\hline 9 & 26 & 29 & 6 & \\
\hline 32 & 33 & 2 & 3 & \\
\hline 20 & 39 & 8 & 3 & \\
\hline 24 & 33 & 10 & 3 & \\
\hline 22 & 15 & 30 & 3 & \\
\hline 31 & 23 & 14 & 2 & \\
\hline 24 & 24 & 21 & 1 & \\
\hline 163 & 199 & 147 & 51 & 560 \\
\hline $29 \%$ & $36 \%$ & $26 \%$ & $9 \%$ & $100 \%$ \\
\hline Sd & D & A & $\mathbf{S a}$ & Total \\
\hline 4 & 23 & 35 & 8 & \\
\hline 12 & 41 & 15 & 2 & \\
\hline 18 & 33 & 17 & 2 & \\
\hline 19 & 38 & 12 & 1 & \\
\hline 21 & 38 & 11 & 0 & \\
\hline 15 & 27 & 22 & 6 & \\
\hline 33 & 31 & 4 & 2 & \\
\hline 24 & 25 & 15 & 6 & \\
\hline 146 & 256 & 131 & 27 & 560 \\
\hline $26 \%$ & $46 \%$ & $23 \%$ & $5 \%$ & $100 \%$ \\
\hline
\end{tabular}

Source: Field Survey. Key: Strongly Disagree (SD), Disagree (D), Agree (A) and Strongly Agree (SA). 
Table 6. Multiple regression output

Descriptive Statistics

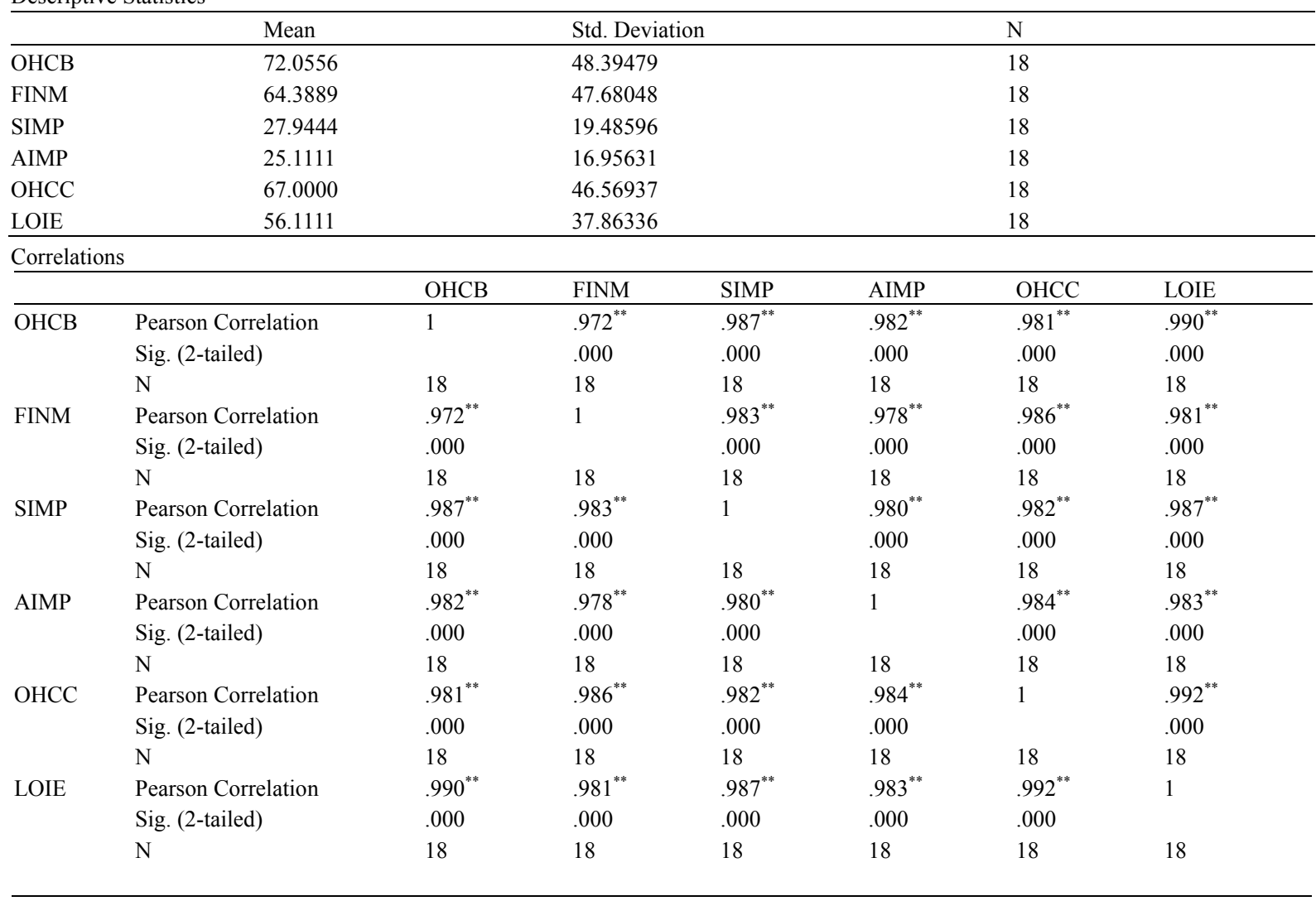

Note: ${ }^{* *}$. Correlation is significant at the 0.01 level (2-tailed).

$\underline{\text { Regression Variables Entered/Removed }}{ }^{\mathrm{a}}$

\begin{tabular}{llll}
\hline Model & Variables Entered & Variables Removed & Method \\
\hline 1 & OHCC, OHCB, FINM, AIMP, SIMP & . & Enter \\
\hline
\end{tabular}

Notes: a. Dependent Variable: LOIE; b. All requested variables entered.

Model Summary

\begin{tabular}{llll}
\hline $\mathrm{R}$ & $\mathrm{R}$ Square & Adjusted R Square & Std. Error of the Estimate \\
\hline $.996^{\mathrm{a}}$ & .992 & .989 & 3.98033 \\
\hline
\end{tabular}

Note: a. Predictors: (Constant), OHCC, OHCB, FINM, AIMP, SIMP.

ANOVA $^{\mathrm{a}}$

\begin{tabular}{lllllll}
\hline Model & & Sum of Squares & Df & Mean Square & F & Sig. \\
\hline 1 & Regression & 24181.661 & 5 & 4836.332 & 305.265 & $.000^{\mathrm{b}}$ \\
& Residual & 190.117 & 12 & 15.843 & & \\
& Total & 24371.778 & 17 & & & \\
\hline
\end{tabular}

Notes: a. Dependent Variable: LOIE; b. Predictors: (Constant), OHCC, OHCB, FINM, AIMP, SIMP.

Coefficients $^{\mathrm{a}}$

\begin{tabular}{|c|c|c|c|c|c|c|}
\hline \multirow{2}{*}{\multicolumn{2}{|c|}{ Model }} & \multicolumn{2}{|c|}{ Unstandardized Coefficients } & \multirow{2}{*}{$\begin{array}{l}\text { Standardized Coefficients } \\
\text { Beta }\end{array}$} & \multirow[t]{2}{*}{$\mathrm{t}$} & \multirow[t]{2}{*}{ Sig. } \\
\hline & & $\mathrm{B}$ & Std. Error & & & \\
\hline \multirow[t]{6}{*}{1} & (Constant) & .833 & 1.804 & & .462 & .652 \\
\hline & $\mathrm{OHCB}$ & .285 & .150 & .364 & 1.900 & .082 \\
\hline & FINM & -.035 & .145 & -.044 & -.241 & .814 \\
\hline & SIMP & .282 & .398 & .145 & .709 & .492 \\
\hline & AIMP & -.071 & .380 & -.032 & -.186 & .856 \\
\hline & $\mathrm{OHCC}$ & .461 & .161 & .567 & 2.865 & .014 \\
\hline
\end{tabular}

Note: a. Dependent Variable: LOIE. 